\title{
CMPC Exam for Recertification: The Good, The Bad, The Reality
}

\author{
Carrie B. Scherzer \\ Justine J. Reel \\ Mount Royal University \\ University of North Carolina Wilmington
}

\begin{abstract}
In this commentary, we try to present a balanced look at the issues surrounding the implementation of the certification exam for recertification purposes. We recognize that the changes to certification are complex and varied, as were reactions by the membership of the Association for Applied Sport Psychology (AASP). As long-standing AASP members who are also certified consultants, we look at the costs, benefits, and ultimately the reality of the CMPC exam for recertification.
\end{abstract}

Keywords: certification, commentary, sport psychology

The thought of studying for and taking a certification exam is daunting, perhaps more so for mid- or even late- career sport psychology professionals. Some of us are years, even decades, from formal graduate education and/or the practice of sport and exercise psychology. We earn our paychecks through a variety of careers: academia, administration, providing psychological services, or business. Importantly, we have held our sport psychology certification for years because we worked hard to achieve the CC-AASP credential and believed it was essential to carry the credential to move the field forward. For some of us, the CC-AASP following our names represented a loose chain connecting us to our roots and the sport psychology community. The credential was also a symbolic means to demonstrate we were paving the way for those coming after us. When it was announced last year that the certification mark would have a new name, Certified Mental Performance Consultant (CMPC), there was uproar and upheaval in the rank and file. When current CC-AASP holders were informed in no uncertain terms that to recertify and maintain the CMPC mark, all CC-AASPs would have to take the certification exam, there was even more fury. Why should we have to sit for an exam after completing all the requirements associated with initial certification and recertification over the years? In this piece, we examine the reasons why having to take the CMPC exam can be good, why it can be bad, and the reality of the situation for people who transition from CC-AASP to CMPC.

Carrie B. Scherzer is with the Dept. of Psychology, Mount Royal University, Calgary, Alberta, Canada. Justine J. Reel is with College of Health \& Human Services, University of North Carolina Wilmington, Wilmington, NC. Address author correspondence to Carrie B. Scherzer at cscherzer@mtroyal.ca. 


\section{The Good}

As a former chair of the Certification Review Committee (CRC) of the Association for Applied Sport Psychology (AASP) (CBS), the first author wholeheartedly agrees with streamlining requirements for certification. The former certification requirements seem to have been designed to make everyone happy (i.e., with representative coursework from all areas and applied experience), but ultimately didn't achieve that and often created much discussion and debate in the CRC. It was fairly easy for us to determine if a class was three graduate level credits of research methods, but some classes were so nuanced or specific, it was hard to determine if the class truly met a criterion. There were also times when a class had been approved to meet a criterion in the past, so students assumed it would continue to be approved; however, when the content changed and the course no longer truly fit, we were hamstrung by precedent. We were also tasked to evaluate not only course content, but instructor credentials if a candidate requested we consider a course from a non-accredited school. All this to state that even though the intentions of the portfolio system were good, it would be difficult to agree every CC-AASP had the same minimum coursework competencies. The certification exam was meant to achieve that benchmark. This is not to suggest there are CRC-certified people who did not meet minimum requirements, but rather that the requirements at times were quite basic. The exam will level the playing field to some extent, in that everyone who passes it will have a standard minimum level of knowledge. So, while the exam may seem like an expensive inconvenience to people who already have CCAASP designation, it does serve a larger, nobler purpose.

\section{The Bad}

It is not surprising many people who have the CC-AASP credential are less than thrilled at the prospect of taking the CMPC exam for recertification. Some of the reasons are clear - the cost of the exam, the energy needed to prepare for and take the exam, and the time that has lapsed since one has received formal education in sport and exercise psychology. In addition, while the exam introduces a minimum standard of competency, it doesn't solve the concerns of the portfolio of courses and the quality of mentorship candidates receive. The exam requirement for all CMPCs has raised several questions. For example, why do CMPCs need to take an exam when they complete necessary continuing education requirements, pay certification fees, attend AASP conferences, and remain active AASP members? How does AASP expect to grow the CMPC credential if there are members who will discontinue certification when it is time to renew?

With the requirement of a certification exam, the AASP and CMPC risk becoming irrelevant to veteran members. Currently, many of our sport and exercise psychology colleagues from graduate school no longer attend AASP and are now involved with other organizations. AASP may be losing sight of institutional history along with the importance of promoting diversity and inclusiveness in our profession. AASP has a strong tradition of being student-centered and has always carefully considered actions or policies that could negatively affect students. One of the gravest concerns about discontinuing certification is what will happen 
to CMPC mentees. The second author has observed first-hand the challenges of students trying to locate a qualified, nearby person willing to take on the service commitment. There is no incentive to serve as a supervisor/mentor for a student who does not attend one's university. Most junior faculty members are instructed to protect their time and not take on too many service activities. AASP may wish to carefully consider input from CMPCs who have been in the field for many years; my voice echoes many colleagues who have made similar grumblings. There should be a way to maintain the rigor and quality of the sport psychology credential without alienating current CMPC mentors and limiting opportunities for students. While working with supervisees can be personally rewarding, the sacrifices of supervisors must be recognized as a deterrent to renew certification and sit for the exam.

\section{The Reality}

After several delays, the CMPC exam is now live (Vealey, 2018) and a reality for anyone who wants to pursue certification or recertify as a CMPC. The exam is a necessary evil for the CMPC mark to be accredited through the National Commission for Certifying Agencies (NCCA). The NCCA does not allow grandfathering, so while CC-AASP did, CMPC cannot (Interim Certification Council, 2017). The Certification Council (CC) has provided an alternate path for people who do not hold a CMPC credential to mentor CMPC candidates, but unless employed at a university with a sport psychology training program, one must wonder why anyone would sign up for this. To be a non-certified mentor, one must have education and training similar to CMPCs, register with the CC (and renew every 5 years), and complete continuing education requirements (Association for Applied Sport Psychology, 2018).

The barrier of cost has been addressed by AASP, in part, by keeping the exam cost as low as possible for CMPCs seeking recertification. First time applicants pay $\$ 375$ to have an application considered and to take the exam; CMPCs seeking recertification pay $\$ 275$ for the exam and the 5-year recertification cycle (normally \$125) (Certification Council, 2017). The fact is it cost money to develop the test, and there are expenses associated with having it available in testing centers worldwide.

The reality, whether individual AASP members or individual CMPCs like it or not, is to be certified or to recertify, everyone must take the CMPC exam. We hope we've shed some light on different perspectives and hope to keep people engaged, but at the end of the day, this is what it is.

\section{References}

Association for Applied Sport Psychology. (2018, May 1). Registry of approved mentors. Retrieved from http://www.appliedsportpsych.org/certification/registry-of-approvedmentors/

Certification Council. (2017, November 15). FAQs answered by the certification council [Electronic mailing list message]. Retrieved from http://www.appliedsportpsych.org/ certification/certification-program-updates/ 
Interim Certification Council. (2017, June 5). June 2017 update [Electronic mailing list message]. Retrieved from http://www.appliedsportpsych.org/certification/ certification-program-updates/june-2017-update/

Vealey, R. (2018, March 27). CMPC certification exam now open [Electronic mailing list message]. 